\title{
PREPARATION OF ACTIVATED CARBON FROM HELHELOK STONES BY CHEMICAL ACTIVATION
}

\author{
Alarqam Z. Tareq ${ }^{\text {a, } *}$, Mohammed S. Hussein ${ }^{\text {a }}$ and Pyman A. Abdujabar ${ }^{\text {a }}$ \\ ${ }^{a}$ Dept. of Chemistry, Faculty of Science, University of Zakho, KRG-Iraq (alarqam.tareq@uoz.edu.krd)
}

Received: Jul. 2018 / Accepted: Sept., 2018 / Published: Sept., 2018

https://doi.org/10.25271/sjuoz.2018.6.3.512

\begin{abstract}
:
In his study activated carbon was prepared from Helhelok stones as a raw material by using chemical activation with zinc chloride $(\mathrm{ZnCl} 2)$ as a chemical agent with the concentration $40 \%$ for $25 \mathrm{~h}$ at $\left(25^{\circ} \mathrm{C} \pm 2\right)$. The optimum conditions were approved in having carbonization temperature $400^{\circ} \mathrm{C}$ for $1 \mathrm{~h}$ to get a maximum percentage of yield $56 \%$. Other properties of the prepared activated carbon were also studied such as $\mathrm{pH}$, ash content, density, moisture content, conductivity, iodine number and methylene blue dye absorbance. Eventually the prepared activated carbon in this work has obtained good characteristics that make it play an essential role in industrial uses and compared it with commercial standard sample from B. D. H Company.
\end{abstract}

KEYWORDS: Activated Carbon, Helhelok, Chemical activation, Zinc chloride.

\section{INTRODUCTION}

Generally, Activated carbon can be categorized within the amorphous carbonaceous materials that are characterized by their high porosity and surface area [1]. It has an effective role in a wide range of environmental applications especially in the eco-protection, water and wastewater treatment [2]. Unpractically, it is created from any carbonaceous materials with a big amount of the natural or synthetic carbon element. Many factors like the availability, cost, purity and manufacturing process can affect tremendously in choosing the starting material or the precursor besides the main product applications ,which are both used to produce the activated carbon.

The physical activation is summarized by carbonizing precursors in a static environment to bring the non-carbonic elements out to be followed by activation within the existence of the factors of oxidize gasifying in a hotter circumstances [35]. However, the chemical out can mainly be implemental through saturation process with chemical agents like $\left(\mathrm{ZnCl}_{2}\right.$ and $\mathrm{FeCl}_{3}$ )[4-6], alkali ( $\mathrm{KOH}$ and $\mathrm{K}_{2} \mathrm{SO}_{3}$ )[7-8] or acids such as phosphoric acid [9]. All these agents can be contribute in developing the porosity through dehydration reactions of the activating factors [10]. It is worth to refer to the tremendous role of the activated carbon in the adsorption and catalysis processes due to high-developed porous structure with its significant adsorption capacity. A lot of studies are also discussing the activated carbon preparation [11-12]. Among of them, Helhelok is a famous plant that usually grows in Zakho Mountains in Kurdistan Region, Iraq, it used a herbal medicine to the neurological colon irritation.

In this study, Helhelok stones were used as a raw material in optimizing the preparation of the activated carbon. Chemical activation was used with the chemical agent zinc chloride $\left(\mathrm{ZnCl}_{2}\right)$. The time and temperature of the carbonization process had their effects also and had to be studied and tested besides adsorption performance towards the methylene blue dye.

\section{MATERIALS AND METHODS}

\subsection{Materials}

Helhelok, the natural raw material, was collected from Zakho Mountains in Kurdistan Region, Iraq. Iodine (>98\%), potassium iodide (>98\%), Na2S2O3(>99\%), methylene blue dye(>98\%), $\mathrm{HCl}(36-38 \%)$, commercial activated carbon and Zinc chloride ( $\mathrm{ZnCl} 2(>98 \%))$ were purchased from BDH chemical company, UK.

\subsection{Methods}

2.2.1 Precursor: In this study, the preparation of the activated carbon was synthesized from the precursor Helhelok stones. These stones were initially rinsed with deionized water to remove impurities and followed by drying for $24 \mathrm{~h}$ in oven at $100^{\circ} \mathrm{C}$ as shown in Fig. 1 (A) and then crushed by disk mill as shown in Fig. 1 (B).
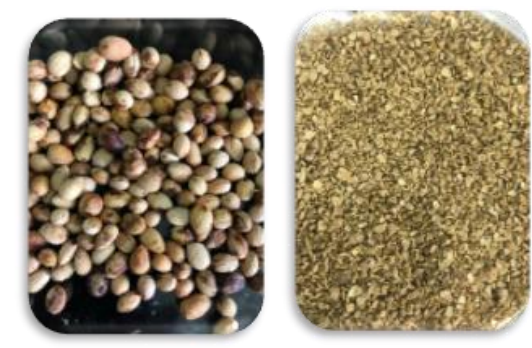

Figure 1. A-Helhelok stones, B-Helhelok crushed

2.2.2 Preparation Of Activated Carbon: Weight $25 \mathrm{~g}$ of dried precursor was mixed with $250 \mathrm{ml}$ of $40 \% \mathrm{ZnCl} 2$ [13] as an activation agent. A stirring of $150 \mathrm{rpm}$ was continuing for $24 \mathrm{~h}$ at $25^{\circ} \mathrm{C}$, followed by filtration and washing with deionized water repeatedly. Lastly, the resulted sample was dried at $110^{\circ} \mathrm{C}$. this result was then carbonized in carbolate tube furnace (MTF12/38/400) at $5^{\circ} \mathrm{C} / \mathrm{min}$ consistently. Different

\footnotetext{
* Corresponding author

This is an open access under a CC BY-NC-SA 4.0 license (https://creativecommons.org/licenses/by-nc-sa/4.0/)
} 
carbonization time and temperature, $(1-3 \mathrm{~h})$ and $\left(400-700^{\circ} \mathrm{C}\right)$ respectively, were used. Wherever the time was finished, the sample was taken out of the tubular furnace to be cooled. After cooling, it was soaked for $24 \mathrm{~h}$ with $(0.1 \mathrm{M}) \mathrm{HCl}$ solution $(10 \mathrm{ml} / \mathrm{g})$ at $\left(25^{\circ} \mathrm{C} \pm 2\right)$ in order to separate the residual zinc chloride. The sample was subject to filtration and washing with deionized water till the filtrate reaches to $\mathrm{pH}$ 6.5-7 [14]. After that, the product was dried for $24 \mathrm{~h}$ at $110^{\circ} \mathrm{C}$ and, then stored in glass vial for the following analyses. Fig. 2 shows the preparation of activated carbon.

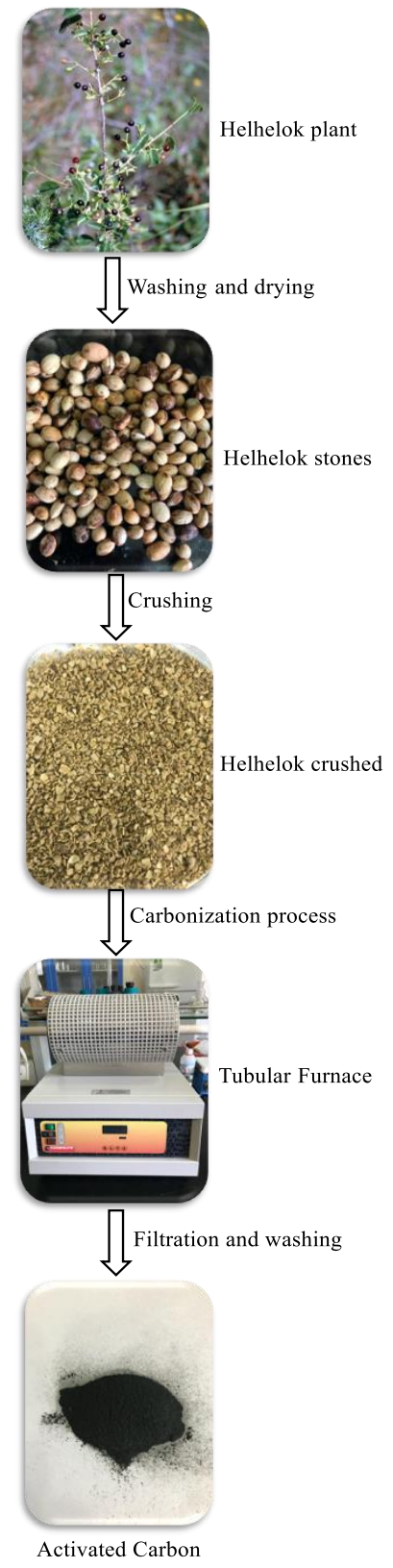

Figure 2. Preparation of activated carbon.

\subsection{Activated Carbon Measurements}

2.3.1 Activated Carbon Yield: The percentage value of activated carbon yield was calculated as follows:

$$
\text { Yeild } \%=\frac{\mathrm{W}_{\mathrm{t}}}{\mathrm{W}_{0}} * 100
$$

where $\mathrm{W}_{\mathrm{t}}$ represents the weight $(\mathrm{g})$ of dry final sample of activated carbon and $\mathrm{W}_{0}$ stands for the weight $(\mathrm{g})$ of the dry precursor.
2.3.2 Activated Carbon Density: It is familiar that bulk density can be considered to mean the mass of a unit volume of the sample in air. In order to investigate the density of our prepared carbon, it was necessary to depend on the ASTM D2854-70 by using $10 \mathrm{~cm} 3$ of the sample and weighting it by graduated cylinder. Thus, it was calculated as follows:

$$
\mathrm{D}=\frac{\mathrm{M}}{\mathrm{V}}
$$

where $\mathrm{D}$ is the bulk density, M stands for mass of dry activated carbon, and $\mathrm{V}$ is the cylinder volume of dry activated carbon (ml).

1. Total Ash Content: A standard method (ASTM D-2866-94) was used to determine the ash content of the activated carbon $3 \mathrm{~h}$ at $400^{\circ} \mathrm{C}$.

Finally, the ash content was assessed by the following:

$$
\mathrm{Ash} \%=\frac{\mathrm{W}_{\mathrm{c}}-\mathrm{W}_{\mathrm{t}}}{\mathrm{W}_{0}}
$$

Where Wc means the weight of crucible containing ash $(\mathrm{g})$, Wt is the weight of empty crucible(g) and W0 represents the weight of the original used activated carbon $(\mathrm{g})$.

2. Moisture Content of Activated Carbon: ASTM D-2867-83 was basically used in this test. A given weight of the sample was heated in preheated oven for $3 \mathrm{~h}$ at $150^{\circ} \mathrm{C}$ in order to measure the moisture content and then calculate it by following:

$$
\text { Moisture } \%=\frac{\mathrm{W}_{\mathrm{c}}-\mathrm{W}_{\mathrm{t}}}{\mathrm{W}_{0}} * 100
$$

Where $W_{c}$ means the weight of crucible with original sample $(\mathrm{g}), \mathrm{W}_{\mathrm{t}}$ is the weight of crucible with dry activated carbon $(\mathrm{g})$ and $\mathrm{W}_{0}$ represents the weight of the original sample $(\mathrm{g})$.

3. PH Measurement: A half gram of the sample was immersed in $50 \mathrm{ml}$ of deionized water accompanied by $150 \mathrm{rpm}$ stirring for $1.5 \mathrm{~h}$. At last, the $\mathrm{pH}$ of slurry was measured by $\mathrm{pH}$ meter (CyberScan 510pc).

4. Iodine Number Measurement: To measure the iodine number of the activated carbon, $10 \mathrm{ml}$ of $(0.1 \mathrm{~N})$ iodine solution was placed in conical flask to be titrated with $(0.1 \mathrm{~N}) \mathrm{Na}_{2} \mathrm{~S}_{2} \mathrm{O}_{3}$ with two drops of $1 \%$ starch solution as indicator. The burette reading was coincident to $\mathrm{V}_{\mathrm{b}}$.

Then, a process of placing $0.05 \mathrm{~g}$ of activated carbon in a conical flask is done. The conical flask had already contained $15 \mathrm{ml}$ of $(0.1 \mathrm{~N})$ iodine solution. This was followed by shaking and filtration. In the next step, $10 \mathrm{ml}$ of the filtrate was titrated with standard sodium thiosulfate solution with adding 2 drops of $1 \%$ starch solution as indicator. At this time, the burette reading was very coincident to $\mathrm{V}_{\mathrm{s}}$. To find out the iodine number, this following calculation was used:

$$
\mathrm{IN}=\frac{\left(\mathrm{V}_{\mathrm{b}}-\mathrm{V}_{\mathrm{s}}\right) * \mathrm{~N} * 126.9 *(15 / 10}{\mathrm{M}}
$$

Where $\mathrm{N}$ stands for Na2S2O3 normality, (126.9) is the atomic weight of $\mathrm{I}_{2}, \mathrm{M}$ presents the mass of the activated carbon.

5. Conductivity Measurement: For conductivity measurement, it was important to mix $1 \mathrm{~g}$ of activated carbon with $100 \mathrm{ml}$ of deionized water for $30 \mathrm{~min}$ accompanied by $150 \mathrm{rpm}$ stirring. Then, electrical conductivity was obtained at $25^{\circ} \mathrm{C}$ by (Wagtech international) conductivity meter with values micro siemens per meter $(\mu \mathrm{s} / \mathrm{m})$.

6. Methylene Blue Dye Uptake Measurement: This measurement is carried out by adding specifically $0.1 \mathrm{~g}$ of the prepared activated carbon to $20 \mathrm{ppm}$ methylene blue dye as aqueous solution placed in a conical flask. Then, an electrical shaker (Lab Tech LSB-015S) was used to shake the solution for $24 \mathrm{~h}$ at $25^{\circ} \mathrm{C}$. After that a UV-Visible spectrophotometer 
(Perkin Elmer Lambda) at $\lambda \max 665 \mathrm{~nm}$, was used to assess the solution absorbance.

It is worth to know that the result of activated carbon concentration of methylene blue value was estimated as milligrams of methylene blue adsorbed per $1 \mathrm{~g}$ of activated carbon.

\section{RESULTS AND DISCUSSION}

\subsection{Effect of Carbonization Temperature}

It can be seen that Fig. 3 explains the effect of carbonization temperature on the prepared activated carbon yield. The carbonization temperature shows remarkable rise starting from $400^{\circ} \mathrm{C}$ till $700^{\circ} \mathrm{C}$.

The yield reached to the maximum percentage $56 \%$ at $400^{\circ} \mathrm{C}$ for $60 \mathrm{~min}$ and then it started to decrease after $3 \mathrm{~h}$ to be $37 \%$ at the same temperature indicating that it was completely burned. However, at $700^{\circ} \mathrm{C}$, the yield had a maximum value $31 \%$ after $1 \mathrm{~h}$. Then, it decreased significantly to $26 \%$ after $3 \mathrm{~h}$. In other words, it is noticed that the yield rate had decrease when a stable structure was formed. It was noted that the increase in the temperature causes a decrease in the adsorption capacity [15]. However, high activation temperatures lead to an obvious decrease in the micropore volume, in contrary to the macropore volume which will increase. All that will result in minimizing the specific surface area of the resulted activated carbon as a reaction to the burning of some micropore walls to formulate mesopore or macropore. On the other hand, a decrease in the temperatures leads to highly developing the microporosity of an activated carbon and results in a high specific surface area [16]. This approves the idea of that the higher temperature we have, the wider micropores we get [17]. Therefore, to have a best optimization temperature between $400-700^{\circ} \mathrm{C}$, the temperature $400^{\circ} \mathrm{C}$ is the choice.

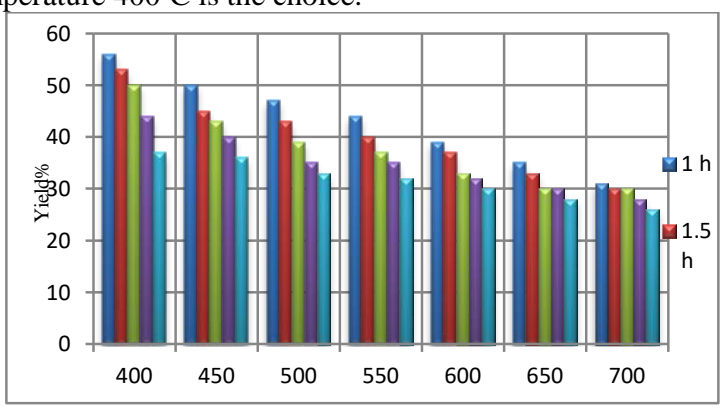

Figure 3. Effect of carbonization time and temperature on the yield percentage of the prepared activated carbon.

\subsection{Effect of Carbonization Time}

Fig. 3 shows that the carbonization temperature treatment was one at different periods of time ranging from 1-3h. Thus, it was concluded that the best time at the best temperature $\left(400^{\circ} \mathrm{C}\right)$, led to a maximum yield percentage $56 \%$. However, the percentage turned down to be $50 \%$ and $37 \%$ after 2 and 3 hours respectively. In addition, the increase of activation time will decrease the micropore volume of activated carbon, while the mesopore volume showed little variation and the macropore volume increase [17]. In summary, all experiments were initiated at the optimum temperature $400^{\circ} \mathrm{C}$ and the heating time treatment is $1 \mathrm{~h}$.

\subsection{Characterization of Activated Carbon Prepared at Optimum Conditions}

All the characterizations of the result activated carbon and commercial activated carbon are shown in table I.
Table 1. characterizations of prepared activated carbon and commercial activated cabon.

\begin{tabular}{|c|c|c|}
\hline Characteristic & prepared & Commercial \\
A.C. & A.C. \\
Yield $(\%)$ & 56 & \\
Bulk density $(\mathrm{g} / \mathrm{ml})$ & 0.3286 & 0.302 \\
Ash content $(\%)$ & 3.88 & 3.2 \\
Moisture content $(\%)$ & 5.08 & 8.05 \\
$\mathrm{pH}$ & 6.21 & 6.8 \\
Conductivity $(\mu \mathrm{s} / \mathrm{m})$ & 549 & 430 \\
Iodine number $(\mathrm{mg} / \mathrm{g})$ & 934.64 & 889.7 \\
\hline
\end{tabular}

One of these important characteristics of the activated carbon is bulk density which is described as a measure of the amount of adsorbent. The carbon can hold per unit volume of bulk density including the pores and voids between particles. Thus, it could be clear that the higher density it had, the more mechanical strength would be [18]. Precisely the density of the activated carbon derived from Helhelok is $0.3286 \mathrm{~g} / \mathrm{ml}$.

On the other hand, whenever density was becoming smaller, the pores were becoming larger and the surface area is getting more available with the activated carbon. So, the adsorption capacity was proportionally inversed with density increase.

Another characteristic of the prepared activated carbon is its ash content which was good value $3.88 \%$ that refers to its high purity, which agrees with the study of Y. Juan and Q. Ke-Qiang [2]. In contrary, high amount of ash content gives a negative effect on the activated carbon even if reduces the mechanical strength and hence effects on the adsorption capacity [20].

Moisture content of the activated carbon had a percentage of $5.09 \%$. It diluted the activated carbon without any effects on the adsorption power. That additional moist weight of the carbon was essential to obtain the dry weight. These findings are in greatly agrees with the result obtained by Y. Juan and Q. Ke-Qiang [2]. Iodine number of the activated carbon was estimated as $934.64 \mathrm{mg} / \mathrm{g}$. Removing iodine by the activated carbon had an indication of its tend to adsorb low molecular weight compounds. The higher percentage of iodine that the activated carbon removed, the higher surface area was available. That high degree of iodine adsorption gave a high surface area and big microspores structure [19].

Surface acidity was also an essential characteristic of the activated carbon in detecting several decomposition reaction, catalytic reaction and absorbent properties [20]. This acidity $(\mathrm{pH})$ of activated carbon represents to the $\mathrm{pH}$ of the activated carbon suspension in water. As it is clear that the lower $\mathrm{pH}$ cause an increase in the capacity [21]. In this study, this $\mathrm{pH}$ had a value of 6.21. This activation process had a significant effect in increasing the surface area and porosity besides the surface basicity of carbon activation, while the conductivity of the activated carbon was $549 \mu \mathrm{s} / \mathrm{m}$ at $35^{\circ} \mathrm{C}$.

The result of the absorbance value of the activated carbon was estimated $319.35 \mathrm{mg} / \mathrm{g}$, which refers to the high adsorptive capacity. Therefore, the activated carbon adsorbed the methylene blue dye with the disappearance of the blue color of the dye in the adsorption process. This capacity of the adsorption was providing the activated carbon with its high surface area.

\section{CONCLUSION}

Preparing activated carbon from Helhelok stones with zinc chloride as a chemical agent was based on different operational parameters like carbonization time and temperature. They were studied to get the optimum conditions were indicated that $\mathrm{ZnCl} 2$ was a suitable activating agent for preparing activated carbon of $56 \%$ yield for $60 \mathrm{~min}$ at $400^{\circ} \mathrm{C}$. The ash content was $3.88 \%$. Iodine number was $934.64 \mathrm{mg} / \mathrm{g}$, density $0.328 \mathrm{mg} / \mathrm{ml}$ and methylene blue dye adsorption $319.35 \mathrm{mg} / \mathrm{g}$. 


\section{ACKNOWLEDGMENT}

Authors are thankful to University of Zakho-KRG-Iraq, for providing facilities to carry out the present work.

\section{REFERENCES}

[1] G.ElShafei, I. ElSherbiny, A. Darwish, and C. Philip, "Silkworms' feces-based activated carbons as cheap adsorbents for removal of cadmium and methylene blue from aqueous solutions," Chem. Eng. Res. Des., vol. 92, no. 3, pp. 461-470, 2014.

[2] Y. Juan and Q. Ke-Qiang, "Preparation of activated carbon by chemical activation under vacuum," Environ. Sci. Technol., vol. 43, no. 9, pp. 3385-3390, 2009.

[3] Z. Liu, Y. Huang, and G. Zhao, "Preparation and characterization of activated carbon fibers from liquefied wood by $\mathrm{ZnCl}_{2}$ activation," BioResources, vol. 11, no. 2, pp. 3178-3190, 2016.

[4] J. Hayashi, A. Kazehaya, K. Muroyama, and A. Watkinson, "Preparation of activated carbon from lignin by chemical activation," Carbon N. Y., vol. 38, no. 13, pp. 1873-1878, 2000.

[5] A. Lua and J. Guo, "Activated carbon prepared from oil palm stone by one-step CO2 activation for gaseous pollutant removal," Carbon N. Y., vol. 38, no. 7, pp. 1089-1097, 2000.

[6] F. Avelar, M. Bianchi, M. Gonçalves, and E. da Mota, "The use of piassava fibers (Attalea funifera) in the preparation of activated carbon," Bioresour. Technol., vol. 101, no. 12, pp. 4639-4645, 2010.

[7] D. Lozano-Castello, M. Lillo-Rodenas, D. Cazorla-Amoros, and A. Linares-Solano, "Preparation of activated carbons from Spanish anthracite: I. Activation by $\mathrm{KOH}$," Carbon $N$. Y., vol. 39, no. 5, pp. 741-749, 2001.

[8] J. Hayashi, M. Uchibayashi, T. Horikawa, K. Muroyama, and V. Gomes, "Synthesizing activated carbons from resins by chemical activation with $\mathrm{K}_{2} \mathrm{CO}_{3}$," Carbon N. Y., vol. 40, no. 15, pp. 2747-2752, 2002.

[9] A. Puziy, O. Poddubnaya, A. Martınez-Alonso, F. SuárezGarcia, and J. Tascón, "Synthetic carbons activated with phosphoric acid III. Carbons prepared in air," Carbon N. Y., vol. 41, no. 6, pp. 1181-1191, 2003.

[10] J. Li, D. Ng, P. Song, C. Kong, and Y. Song, "Preparation and characterization of high-surface-area activated carbon fibers from silkworm cocoon waste for congo red adsorption," Biomass and Bioenergy, vol. 75, pp. 189-200, 2015.

[11] A. Kumar and H. Jena, "High surface area microporous activated carbons prepared from Fox nut (Euryale ferox) shell by zinc chloride activation," Appl. Surf. Sci., vol. 356, pp. 753-761, 2015.

[12] A. Jain, R. Balasubramanian, and M. Srinivasan, "Hydrothermal conversion of biomass waste to activated carbon with high porosity: A review," Chem. Eng. J., vol. 283, pp. 789-805, 2016.

[13] R. Baccar, J. Bouzid, M. Feki, and A. Montiel, "Preparation of activated carbon from Tunisian olive-waste cakes and its application for adsorption of heavy metal ions," J. Hazard. Mater., vol. 162, no. 2-3, pp. 1522-1529, 2009.

[14] I. Tan, B. Hameed, and A. Ahmad, "Equilibrium and kinetic studies on basic dye adsorption by oil palm fibre activated carbon," Chem. Eng. J., vol. 127, no. 1-3, pp. 111-119, 2007.

[15] A. Algidsawi, "A Study of ability of adsorption of some dyes on activated carbon from date's stones," Aust. J. Basic Appl. Sci., vol. 5, no. 11, pp. 1397-1403, 2011.

[16] H. Zhang, Y. Yan, and L. Yang, "Preparation of activated carbons from sawdust by chemical activation," Adsorpt. Sci. Technol., vol. 26, no. 7, pp. 533-543, 2008.

[17] B. Xu, Y. Chen, G. Wei, G. Cao, and H. Zhang, "Activated carbon with high capacitance prepared by $\mathrm{NaOH}$ activation for supercapacitors," Mater. Chem. Phys., vol. 124, no. 1, pp. 504-509, 2010.

[18] D. Adinata, W. Daud, and M. Aroua, "Preparation and characterization of activated carbon from palm shell by chemical activation with $\mathrm{K}_{2} \mathrm{CO}_{3}$, , Bioresour. Technol., vol. 98, no. 1, pp. 145-149, 2007.

[19] W. Bae, J. Kim, and J. Chung, "Production of granular activated carbon from food-processing wastes (walnut shells and jujube seeds) and its adsorptive properties," J. Air Waste Manage. Assoc., vol. 64, no. 8, pp. 879-886, 2014.

[20] A. Abdullah, A. Kassim, Z. Zainal, M. Hussien, and D. Kuang, "Preparation and characterization of activated carbon from gelam wood bark (Melaleuca cajuputi)," Malaysian J. Anal. Sci., vol. 7, no. 1, pp. 65-68, 2001.

[21] S. Senthilkumaar, P. Kalaamani, K. Porkodi, P. Varadarajan, and C. Subburaam, "Adsorption of dissolved reactive red dye from aqueous phase onto activated carbon prepared from agricultural waste," Bioresour. Technol., vol. 97, no. 14, pp. 1618-1625, 2006. 